\title{
Kernos
}

Revue internationale et pluridisciplinaire de religion grecque antique

$11 \mid 1998$

Varia

\section{The Middle Ground: Philoktetes in Italy}

Irad Malkin

\section{CpenEdition}

\section{Journals}

\section{Electronic version}

URL: http://journals.openedition.org/kernos/1221

DOI: 10.4000/kernos. 1221

ISSN: 2034-7871

\section{Publisher}

Centre international d'étude de la religion grecque antique

Printed version

Date of publication: 1 January 1998

ISSN: 0776-3824

\section{Electronic reference}

Irad Malkin, «The Middle Ground: Philoktetes in Italy », Kernos [Online], 11 | 1998, Online since 21 April 2011, connection on 03 May 2019. URL : http://journals.openedition.org/kernos/1221 ; DOI : 10.4000/ kernos. 1221 


\section{The Middle Ground: Philoktetes in Italy}

Newly established city states, such as Kroton and Sybaris, usually imported their cults. Measures of syncretism with religious practices and ideas of native populations have often been argued for, but these usually relate to the subsequent histories of new cities, not to the time of foundation. There was one exception: the cult of the oikistes, the founder of the city. These founders, not mythological heroes but historical figures, were buried in the agora and received a hero's cult. This cult was the first cult which truly belonged to the new city state, a patriotic cult around which it focused its historical beginnings and self identity. It was a cult which, by definition, could not have been imported from a mother city, and, also by definition, was impossible to share with others.

However, during the course of their existence, some Greek colonies were no longer satisfied with such a human-heroic focus, but looked for a heroic pantheon which was either common with, or at least as ancient, as the panhellenic heroic pantheon. By the middle of the fifth century a city such as Kroton whose oikist was Myskellos of Rhypai, seems to have created for itself heroic origins which reached far into the mythic past, by-passing Myskellos. The coinage of Kroton showed Herakles with the explicit legend,

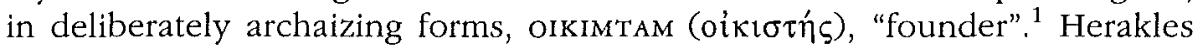
overshadowed the city's historical founder, Myskellos of Achaian Rhypai, similarly to what happened at Taras, where Phalanthos was overshadowed by the eponymous "Taras". ${ }^{2}$ This was clearly a late development, since Kroton's earliest coinage (sixth century) bears the symbol of the tripod of the Delphic oracle which prophesied to its historical founder, Myskellos of Rhypai. ${ }^{3}$ It is reasonable to assume that the context for the beginning of the emphasis on Herakles may be found toward the end of the sixth century when Philoktetes, Herakles' trusted companion, would have been of paramount importance, as we shall soon see.

1 L. LACROIX, Monnaies et colonisation dans l'Occident grec, Brussels, 1965, p. 76-79; M. Gianglulio, Ricercbe su Crotone arcaica, Pisa, 1989, p. 71.

2 I. MALKIN, Myth and Territory in the Spartan Mediterranean, Cambridge, 1994, p. 133-139.

3 See B.V. HEAD, Historia numorum, Oxford, $1911^{2}$, p. 97, cf. p. 98; C.M. KRAAY, Archaic and Classical Greek Coins, London, 1976, p. 181; Giangiulio, op. cit. (n. 1), p. 7074; I. MALKIn, Religion and colonization in ancient Greece, Leiden, 1987, p. 43-47. 
We should remember what Kroton must have been going through just before its war with Sybaris around 510. Threatened with annihilation by the fantastically rich and powerful enemy, its relief and punishment of Sybaris were expressed proportionally. Ca. 510 BC, Dorieus the Spartan apparently came to its aid; he was on his way to colonize Eryx in Sicily, reclaiming a legacy of his own ancestor Herakles. It seems likely that this rare use of an explicit charter myth impressed the victorious Krotoniates, especially since Herakles was closely associated with a similar myth of the eponymous "Kroton".

In fact, the myths are interconnected. Herakles, who was travelling with the cattle of Geryon on his way back to Greece, was challenged in Sicily by the lord of the land, the eponymous Eryx; winning the match, Herakles left the country in the safe-keeping of its inhabitants until the day came when one of his descendants should return to reclaim it. ${ }^{4}$ Travelling in Italy with the same cattle, Herakles accidentally killed Kroton; he erected a tomb and prophesied to the inhabitants that one day a city will rise, named after the man he had killed. ${ }^{5}$ The Krotoniate myth - unlike the Herakleid myth in Sicily - is not so much a charter myth but a "myth of origins". The idea, expressed in Kroton's coinage, that Herakles was an oikistes, was obviously an extension of the notion of "origins" to that of "foundation", although Herakles does not actually "found" the state. What matters here is the very similar structural relations of the two myths: in both Herakles creates a precedent, a constitutive act. In both he makes a kind of pact with the indigenous people, prophesying (or legitimating) future Greek colonization.

Probably compensating for the inferiority most colonials came to feel in the Classical period with regard to the "epic" mother cities of mainland Greece, this new pride in a past more ancient than the Trojan War may have been the context for a new emphasis placed on Philoktetes. Like the eponym "Kroton", he was another companion of Herakles, the one he seems to have trusted most. ${ }^{6}$ But Philoktetes was there to provide also a more immediate, talismanic reason: winning a war.

Some Greek recipes for winning wars include stealing a Palladion, building a Trojan horse, or bringing Philoktetes from Lemnos together with the bows and arrows of Herakles in order to win the Trojan War. ${ }^{7}$ Kroton did something similar: it was believed that Philoktetes placed the bows and arrows in the frontier country, the Middle Ground, between Kroton and Sybaris. There Philoktetes had founded non-Greek cities, at (Cape) Krimissa,

\footnotetext{
4 I discuss this at length in MALKIN, op. cit. (n. 2), p. 203-219.

5 Diod. Sic., IV, 27, 7; cf. Lacroix, op. cit. (n. 1), p. 77; Gianglulio, op. cit. (n. 1), p. 7374.

6 L. Lacroix, La légende de Philoctète en Italie méridionale, in RBPb, 43 (1965), p. 911.

7 Cf. C. Faraone, Talismans and Trojan Horses: guardian statues in ancient Greek myth and ritual, New York, 1992, passim and ch. 6.
} 
Petelia, Chōne, and Makalla. ${ }^{8}$ Perhaps the professional family of seers, the Iamidai, were involved in this new articulation of the significance of Philoktetes' relics, that victory should be Kroton's if, as before the Trojan war, the bow and arrows of Herakles would be theirs. Herodotus, preoccupied in this context mostly with Dorieus, is silent about this, but he adds that the Iamidai, having just deserted Sybaris, were handsomely compensated following Kroton's victory. ${ }^{\text {? }}$

The term "Middle Ground" refers to the encounter between colonists and native populations which creates what Richard White calls a "Middle Ground", an area in which both play roles according to what each side perceives to be the other's perception of itself. In time this role-playing, the result of a kind of double mirror reflection, creates a civilization that is neither purely native nor entirely colonial-imported. According to changing circumstances each side will also come to emphasize certain aspects of the image constructed of the other, either for the sake of mediation and co-existence or as justification of hostilities. In time, however, it often happens that the Middle Ground gets eroded when one side, such as the French Canadians in Quebec, simply conquer and overtake the land. ${ }^{10}$

It appears therefore that by the end of the sixth century Philoktetes had become a Krotoniate hero, joining with Herakles who, in his turn, becomes the Ktistes of Kroton. This happened in a context of a war between two Greek cities, although those who live in the Middle Ground between them seem to have suffered enormously: their land was annexed and the sacred biera of a Greek hero were taken away. Let us note that up until now Philoktetes was claimed neither by Kroton nor by Sybaris. He resided in the Middle Ground, in the frontier regions mostly in native land. How did Philoktetes initially get involved in all this?

Philoktetes was a Nostos, one of those heroes returning from the Trojan War whose myths were projected onto new lands, articulating landscapes, genealogies, and ethnicities. Nostoi myths provided cultural and ethnic mediation with non-Greeks, and, once integrated, often came to provide the terms of self-perception for native populations. The fifth-century Greek perception of the beginning of history, probably drawing on a long tradition of employing Nostoi as explanations of "origins", gave the Nostoi the role of explaining either the origins of discrete Greek political communities or the

8 D. Musti, Lo suiluppo del mito di Filottete, da Cortone a Sibari, in Épeios et Pbiloctète en Italie: données archéologiques et traditions légendaires, Naples, 1991 (Cabiers du Centre Jean Bérard, 16), p. 23, 26; cf. G. Maddoli, Filottete in "Italia", in L'epos greco in occidente: atti del diciannovesimo convegno di studi sulla Magna Grecia, Taranto, 7-12 Ottobre 1979, Taranto, 1980, p. 144-146.

9 HDT., V, 44-45. Generally on the Iamidai in Kroton, see Giangiulio, op. cit. (n. 1), p. $178-179$.

10 R. WhIтE, The middle ground: Indians, empires, and republics in the Great Lakes region, 1650-1815, Cambridge, 1991. 
ethnic-genealogical origins of nations. History begins with the kinesis following the Nostoi-returns from Troy, as Thucydides' introduction illustrates.

Such a process which started by placing Philoktetes in the Middle Ground at the beginning of Greek colonization, ended with the annexation of Philoktetes to the heroic pantheon of the city. It is curious that many of the Nostoi were localized in the Middle Ground, in frontier regions, not in the centers of colonies. Thus the peripheral Nostoi usually did not justify or legitimate a priori colonial foundations; to illustrate with a contrast, the foundation oracle of Herakleia Pontike, founded in the mid-sixth century, ordered the city be established around the tomb of the Argonaut Idmon, namely a focal point and a central location. The tomb justifies the choice of the site and Idmon becomes, right from the start, a central figure of Herakleia's heroic pantheon ${ }^{11}$. But this is not the case with most of the peripheral Nostoi in the western Mediterranean.

In a forthcoming book I suggest that peripheral sitings may have played a particular role in the Middle Ground. Perhaps the cult of Philoktetes originated in such a Middle Ground, in a Greek wish to approach non-Greeks in ways that might flatter them. Independent relations with peripheral or hinterland peoples were especially important in view of the limited territories of the early colonies, ${ }^{12}$ and the nosto $i$ may have been an important cultural device of mediation. The Middle Ground localizations may also have been the consequence of individual Greeks, whom Strabo calls katoikoi, ${ }^{13}$ moving or settling among non-Greeks in the frontier regions of colonies and establishing for themselves a Nostos cult. At the end of the cycle, as we have just seen with Kroton and Sybaris, the same sitings and Nostos-cults would later (in the late sixth century) come to serve precisely as justifications for expansion, war, and annexation.

The peripheral Nostoi of colonization evoke for me the image of the robe of Nessos. Pierced by Herakles' arrow, the Centaur Nessos tells Deianeira to soak a robe in his blood and hide it from the rays of the sun. If she ever suspects Herakles of falling out of love with her she is to give him the robe and be assured of his devotion. When the day comes and Herakles arrives home from Euboia with the beautiful Iole, Deianeira presents him with the robe. Exposed to the light of day, it clings to Herakles' flesh and devours him. The nosto $i$ too sometimes functioned as gifts of acculturation and mediation, but when exposed to the rays of expansionist ambitions these Nostoi robes would burn their wearers.

11 Malkin, op. cit. (n. 3), p. 73-77.

12 See R.D. Whitehouse, J.B. Wilkins, Greeks and natives in soutb-east Italy: approacbes to the arcbaeological evidence, in T.C. Champion (ed.), Centre and periphery. Comparative studies in arcbaeology, London, 1989, p. 102-126; with E. DENCH, From Barbarians to New Men: Greek, Roman and modem perceptions of peoples in the central Apennines, Oxford, 1995, p. 31.

13 Strabo, VI, 262. 
Philoktetes was a relatively minor hero in the Homeric epics; poetically, however, his role seems to be identified with the final victory, the immediate cause for the fall of Troy and, consequently, with the start of the Nostoi travels. He was at the junction where war ends and wanderings begin. $\mathrm{He}$ is similar in that respect to Epeios who built the Trojan Horse and who also had peripheral siting in Italy. Philoktetes was in charge of Herakles' bow and arrows, without which victory would have never been achieved. ${ }^{14}$ Both the artisan's tools of Epeios, and the bow and arrows of Herakles, became tangible sacred objects, biera, in the colonial region of the Italian heel. ${ }^{15}$ In Homer Philoktetes returns to his Thessalian kingdom; ${ }^{16}$ by contrast, in his western Nostos he reaches Italy and dedicates the arrows of Herakles in a temple of Apollo Alaios, perhaps as a god of "wanderings", there the Nostos ends.

Philoktetes is somewhat atypical in another respect: he is the sick hero, having been bitten by a snake and abandoned on the barbarian island of Lemnos ${ }^{17}$ for almost ten years, before Odysseus came to pick him up with the arms of Herakles. Eventually he would be particularly suited for Kroton, the city which boasted of its numerous Olympic victors and its reputation for health. ${ }^{18}$ But first, as in Lemnos, he was particularly suited to live among barbarians and serve as a hero of acculturation.

Let us observe some of the details: Strabo, following Apollodorus' commentary on the Catalog of Sbips, ${ }^{19}$ says that Philoktetes came to the region of Kroton, colonized Cape Krimissa, ${ }^{20}$ and in the hinterland the city of Chone (after which the Chones are named); some of his companions went ahead to found Segesta in Sicily, under the leadership of the Trojan Aigestes. ${ }^{21}$ Turning to an unnamed source, Strabo adds that Philoktetes came to Italy after his

14 Cf. Little Iliad (Proclus' summary in A. BERNABÉ, Poetarum epicorum graecorum: testimonia et fragmenta, Pars I, Leipzig, 1987); SopH., Pbil., 1439.

15 Cf. Musti, art. cit. (n. 8), p. 23.

16 Od., III, 190; Il., II, 716 ff.

17 Il., II, 722-723; cf. the summaries of Proclus of the Kypria and the Little Iliad (Bernabé), and Sophocles' Philoktetes. For Lemnians as agriopbonoi: Od., VII, 294.

18 MADDOLI (art. cit. [n. 8]) emphasizes this quality of the hero; see also M. Giangiulio, Filottete tra Sibari e Crotone. Osservazioni sulla tradizione letteraria, in Épeios et Pbiloctète, cit. (n. 8), p. 52, with A. MELE, Le origini degli Elymi nelle tradizioni di $v$ secolo, in Kokalos, 39-40, (1993-1994), p. 41. See also G. MadDoli, I culti di Crotone, in Crotone, Atti del ventitresimo Convegno di studi sulla Magna Grecia, Naples, 1984, p. 313430.

\section{F 167 Jacoby.}

20 For the possible ms. confusion between "settle" and "inhabit", see Giangrulio, op cit. (n. 1), p. 44-45 with M. CASEviTz, Le vocabulaire de la colonisation en grec ancien, Paris, 1985 , p. 77-80. I see no reason here to reject the meaning of "founded" merely because confusions were possible,

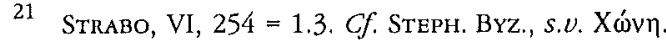


successful return (as in Homer), since he had to leave his Magnesian city Meliboia 22 because of stasis; he then founded Petelia, the "mother city" of all the "Leukanians" or "Chōnes". 23

Both the Aristotelian Mirabilia and Lycophron seem to draw partly on the same source in their versions of the Italian Philoktetes. In Lycophron's Alexandra, ${ }^{24}$ Cassandra prophesies that Philoktetes will be received by the small city Krimissa in the land of the Oinotrians; his tomb will be near the Krathis river by the sanctuary of Apollo Alaios, at the mouth of the river Nauaithos; ${ }^{25}$ there he will be killed by the Pellenian Ausonians when he will help the Lindians (namely, colonists from Rhodes), blown there by the north

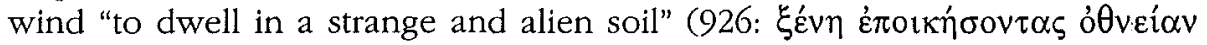
$\chi \theta \operatorname{co}^{\prime} \alpha$ ). In Makalla the natives (encborioi) will build a great sanctuary upon his tomb and will honor him like a god with libations and sacrifices.

The Aristotelian author says that the people of Sybaris have a cult to Philoktetes. Upon his return from Troy the hero went and colonized Makalla in the region of Kroton and dedicated Herakles' bows and arrows in the sanctuary of Apollon Alaios; these arrows were seized by Krotoniates "during their time of power" and were deposited by them in their own temple of Apollo. In the same region Philoktetes has his tomb, after he had been killed by the river Sybaris; he died fighting the local barbarians (sic), together with the Rhodians who came there with Tlepolemos. ${ }^{26}$

The sources imply a rather late date, probably in consequence of the war between Kroton and Sybaris in 510 BC, when the cult of Philoktetes and the biera of Herakles became a bone of contention between the two, relative to the territorial expansion of Sybaris to the south and of Kroton to the north. Philoktetes was taken over by Kroton and transferred, whether from Sybaris to Kroton or to the Sybarite territory Kroton had just won. In the later fifth century (at the earliest) Thourioi, which had replaced Sybaris, challenged Kroton, claiming Philoktetes and the sacred relics for itself; Justin even makes Philoktetes the founder of Thourioi where there was, in the Roman period, a monumentum raised in his memory. The arrows of Herakles were similarly

22 Il., II, 717.

23 Strabo, loc. cit. The reading $\tau \hat{\omega} v$ X $\omega v \omega v$ is based on the foundation of the city Chōne, named also by Strabo. See MAdDoli, art. cit. (n. 8), p. 141 and cf. Virg., Aen., III, 402; Serv., ad loc.; Sil. Ital., XII, 433; Solin., II, 10. See also the survey by G. Gianeldi, Culti e miti della Magna grecia: contributo alla storia piu antica delle colonie grecbe in occidente, Florence, $1963^{2}$, p. 162-167.

24 Lyc., 911-913, 919-929.

25 A river near Kroton, another location for the burning of ships by Trojan women: STrabo, VI, 262.

26 De mir. ausc., 108; Cf. TzETzes, ad Lyc., 911, citing Euphorion, an Alexandrian erudite of the third century, who says that Philoktetes founded the temple of Apollo Alaios, between Kroton and Thourioi. I am skeptical about the reality of Rhodian colonization (sharing Bérard's view), but see MADDol, art. cit. (n. 8), p. 151-159. 
pointed out in the temple of Apollo right there. ${ }^{27}$ Although both Sybaris and Kroton claimed the sacred arrows of Herakles, none seem to have had them originally. Rather, the minor, probably native towns of the frontier zone separating them, were the ones who had once possessed them.

Most of the modern discussion concentrates on exclusive contexts and does not take into consideration a multiplicity of regards. However, Philoktetes mattered, sometimes simultaneously and always differently, to the precolonists sailing by the promontory of Krimissa, the non-Greek frontier communities, the small groups of Greeks who settled among them, and finally the major colonies of Kroton and Sybaris. However, today the state of the discussion is at a diametrically conflicting position about the history of the cult, and both sides appear to assume some kind of exclusivity of context. Domenico Musti argues for a transition of Philoktetes by Kroton to conquered Sybaris; others, such as Gianfranco Maddoli and Maurizio Giangiulio take it the other way around. ${ }^{28}$

Philologically, it has been demonstrated that the relevant texts can indicate a move of Philoktetes (the sacred relics, and even his tomb/heroshrine) to Sybaris. The subject-antecedent of the relevant verbs and pronouns are sufficiently elusive to yield this meaning. According to Musti's

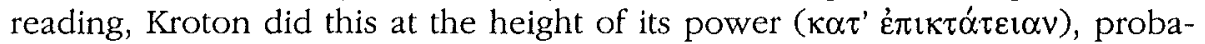
bly after it had won, against unfavorable odds, the war against powerful Sybaris in 510 BC. Musti's idea is just possible, but the motive attributed to Kroton seems doubtful. Kroton, which (according to Musti) cared little for its own heroic ("Mycenaean") past, ${ }^{29}$ transferred Philoktetes to Sybaris as a kind of "indemnification" (risarcimento) towards the divinity (Apollo) of the hostile city, a god who was also honored by Kroton. ${ }^{30}$ Most readers, however, take the more straightforward meaning of the texts in the reverse direction: from Sybaris to Kroton. Mele, for example, thinks that Philoktetes was a hero of Sybaris, violently robbed by Kroton during its epikrateia. ${ }^{31}$ According to this view it was Kroton, at the height of its power, which annexed Philoktetes. In my view this is the correct interpretation, but only partially. The evidence does not point to a worship of Philoktetes in Sybaris itself. Rather, he seems to have been the hero of the land in between Kroton and Sybaris and of its natives. What I have said earlier about the context of the new regard of Herakles as the founder of Kroton seems to support this.

Kroton's war against Sybaris signified also its territorial expansion over the lands in the regions around Cape Krimissa, settled mostly by non-Greek

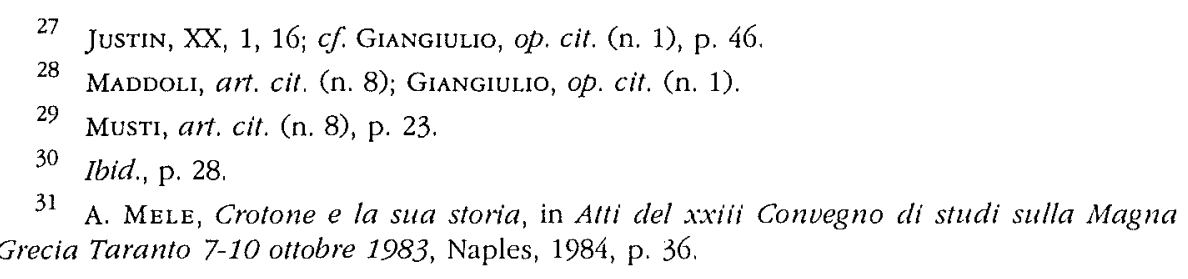


communities. The tradition in the Aristotelian Mirabilia that Philoktetes died by the river Sybaris fighting "barbarians", may have risen following Kroton's annexation of the hero from the barbarians. Reclaiming sacred relics, brought by a Greek hero to a "barbarian" land in the heroic age, seem to have served as a justification for colonial expansion at their expense. In Sicilian Gela, for example, one of its two oikists, Antiphemos of Rhodian Lindos, led military expeditions to the hinterland. He conquered the native city of Omphake, pillaged it, and brought back to Gela a statue "made by Daidalos". ${ }^{22}$ The myth of Daidalos in Sicily provides a fascinating set of mythological precedents, centered especially around Minos, king of Crete who pursued Daidalos to Sicily and was murdered there by Kokalos, the Sicilian king, at the capital city Kamikos. In the seventh century Antiphemos reconnected to a relic, evidence for ancient presence of a Greek hero. The "restitution" of Daidalos' statue, because of its connection with a victory over a native city, is what lends the relic its significance of implied justification of the conquest. With Philoktetes' relics, their restitution apparently served a double purpose: both to justify penetration to the hinterland in relation to non-Greeks (as with Antiphemos) and a claim in inter-Greek rivalry.

This type of legitimation is quite familiar from parallel conquest- and colonization-practices where the remains of the heroes themselves served the purpose, as in the case of Hagnon and the bones of Rhesos at Amphipolis, the transfer of which was actually a "condition" for the success of the colony, as a foundation oracle of Amphipolis says explicitly. ${ }^{33}$ In our case it is important to note that, unlike Amphipolis, the statue of Daidalos or the arrows of Herakles were not strictly connected with the foundation-act of the colony but rather with its subsequent expansion and history. No justification charter-oracle - of the kind Dorieus used when going to Sicily to reclaim a legacy of Herakles - exists for either Kroton, Sybaris, or Gela. In contrast to these major Greek colonies, Sicilian Omphake, or Italian Krimissa, Chōne, Makalla, and Petelia, were all minor, peripheral sites. The use of cult and heroic precedent is applied not to the centers of the new colonies, as at Herakleia Pontike, at the time of their foundation, but to the territorial expansion toward the frontier in later generations, to that which was not initially taken over. With Daidalos or Philoktetes mythological justifications more often had to do with a posteriori situation of territorial expansion from an already founded colony. Also, no divine or heroic "promised land" (such

32 Paus., VIII, 46, 2; cf. T.J. Dunbabin, Minos and Daidalos in Sicily, in BSR, 16 (1948), p. 1-18; The western Greeks: the bistory of Sicily and south Italy from the foundation of the Greek colonies to 480 B.C., Oxford, 1948, p. 112, 318.

33 Polyaen., Strat., VI, 53; cf. Marsyas, 135 F 7 Jacoby; H.W. Parke, D.E.W. Wormell, The Delpbic oracle, Oxford, 1956, vol. 2, p. 133; MALKIN, op. cit. (n. 3), p. 81-84. For the Spartan examples, see MaLkin, op. cit. (n. 2), p. 26-30. For the heroic transfer of relics in general, see R. Pfister, Der Reliquienkult im Altertum, Giessen, 1909 (RGVV, 5, 1.2), p. 188 ff. 
as Sparta itself, according to Tyrtaios, ${ }^{34}$ or Eryx in Sicily) is implied here. Rather, the natives, who appeared to possess sacred objects which were not "rightly theirs", were being punished. The "re-possession" of the objects, whether a statue of Daidalos or the arrows of Herakles or the bones of Theseus, imply Greek legitimation. A Greek heroic "precedent" had once been established; "now", the new colonists redeem the objects and bring about what was once started to its end: Greek territorial appropriation and the reinstallment of the biera.

It is time to reverse the perspective. Why was Philoktetes, during the seventh and sixth centuries, sacred not in the Greek centers but rather in the non-Greek frontier zones? The answer may reveal a complex "Middle Ground". First, a closer observation of the sites involved: Cape Krimissa is probably Punta dell'Alice, some $40 \mathrm{~km}$ north of Kroton; ${ }^{35}$ most of the other sites seem to be in its orbit. ${ }^{36}$ Ciro, at a top of a hill, a few $\mathrm{km}$ to the south, in the hinterland, ${ }^{37}$ could be Chōne; Petelia, which may be identical to Makalla, ${ }^{38}$ may be the site of Strongoli, north of Kroton. ${ }^{39}$ All of these sites are minor, peripheral or hinterland places, and none is mentioned in the sources as a Greek colony. ${ }^{40}$

Who lived in the Middle Ground of Philoktetes? Who were the inhabitants of Krimissa, Petelia, Chōne, and Makalla? The Chōnes were clearly not Greeks and we are therefore concerned here with indigenous sites, located in the frontier zones between the areas of Kroton and Sybaris. It seems reasonable that these cities could escape, for a while, direct Greek domination precisely because of this geo-political situation. However, they probably did not escape acculturation, including the absorption of Greek Nostoi myths. Greek material culture certainly reached them. ${ }^{41}$

I suspect the situation was more complex than a situation of "Greek vs. native". We should be looking for individual Greek families or small Greek

\footnotetext{
34 Tyrtaios, fr Ia Prato.

35 Dunbabin, Westem Greeks, cit. (n. 32), p. 159; Giangiulio, art. cit. (n. 18), p. 229230.

36 LACroix, art. cit. (n. 6), p. 8.

37 Giangivlio, art. cit. (n. 18), p. 44, 224-226

38 J. BÉRARD, La colonisation grecque de l'Italie méridionale et de la sicile dans l'Antiquité : histoire et légende, Paris, $1957^{2}$, p. 347. Makalla: see also STEPH. Byz., s.v. Mók $\alpha \lambda \lambda \alpha$. Cf. Et. Magnum, 574, 16; schol. ad THuc., I, 12.

39 Dunbabin, Western Greeks, cit. (n. 32), p. 161; Giangiulio, art. cit. (n. 18), p. 229.

40 Krimissa is mentioned as a landmark in the foundation oracle to Myskellos: DioD. SIC., VIII, 17, 1.

41 J. de La Genière, C. SABbione, Indizi della Macalla di Filottete? (Le Murge di Strongoli), in Atti e memorie della Societa Magna Grecia, n.s. 24-25 (1983-1984), p. 163-192; Giangiulio, op. cit. (n. 1), p. 43-5 (epigraphic evidence); 224-228 (material culture); $c f$. Giangiulio, art. cit. (n. 18), p. 52.
} 
communities living among the indigenous population, as several entries in Strabo seem to suggest. All this is frustratingly elusive, but the implications of the possibility of Greek presence in non-colonial small communities, perhaps analogous to Gravisca, Pyrgi (and even Amphipolis before its official foundation), ${ }^{42}$ are quite significant for the notions of acculturation and the mythological colonial discourse. The indications in Strabo seem to point to settlement of small groups of Greeks in what he calls katoikiai, in the periphery of both Kroton and Sybaris, among non-Greeks. ${ }^{43}$ These may have been among the twenty five "subject cities". This point of contact may explain the means of "acculturation" - a term used too loosely, too often. It may also explain how siting and localization of the Nostoi of Epeios and Philoktetes initially took place not in the great centers of Sybaris and Kroton, but in the periphery. It seems that local interest developed as a response to a challenge posed by the major colonies, proclaiming as the response of the minor sites a heroic antiquity greater than either Kroton or Sybaris. The indigenous peoples, learning all this from the settlers among them, adopted such beliefs and eventually made them their own.

In the early phases of their history the great colonies would have had no reason to object to this "indigenization" of common Greek heroes. They were not excluded from their pantheon because they did not belong to it initially. On the contrary, Greek heroic associations would constitute useful diplomacy, especially at an early period for which there exists no evidence for feeling of ethnic superiority (articulated in terms of heroic genealogies) in relation to barbarians. On the contrary, it appears that most non-Greeks were "explained" as originally having stemmed from the Greek orbit. The Iapygians, for example, were originally the Cretans men of Minos who came to southern Italy after the death of their king who pursued Daidalos to Sicily.

Heroic origins are seen therefore as answering, simultaneously, the needs of various distinct groups: the Greek settlers among the native communities who may be credited with the initial association with Philoktetes, and the native populations who adopted him. Both would find such origins encouraging in relation to the ever-growing threat of the expansive major colonies who, contra-intuitively to the modern observer, cared little for attributing such origins to themselves. Their land was theirs in any case, and aside from the general Delphic charter of their colonization no specific charter myth was needed to justify the possession of their own sites, at least initially (Herakles as oikist of Kroton would come later). Neither Sybaris nor Kroton would find reason to combat indigenization; rather, Philoktetes-associations could mediate and ameliorate inter-relationships. However, by the end of the sixth

42 B.H. IsAaC, The Greek settlements in Thrace until the Macedonian conquest, Leiden, 1986, p. $4-8$.

43 Cf. Dunbabin, Western Greeks, cit. (n. 32), p. 160: "It is probable that the region received settlers from Greece, who never formed a colony but were in time absorbed by Kroton." 
century, the tables would turn and Philoktetes would need redemption and vindication. He was integrated into the heroic pantheon of Kroton. As for the Middle Ground and the natives who inhabited it - the robe of Nessos, a gift to ensure love, had been exposed to the sun and burnt its wearers.

Tel Aviv University

Irad MALKIN

Department of History

Ramat-Aviv

69978 Tel Aviv

Israel 